\title{
Protein Complex as Indicator of Seed Recalcitrance
}

\author{
Marina I Azarkovich* \\ KA Timiryazev Institute of Plant Physiology, Russia
}

*Corresponding author: : Marina I Azarkovich, KA Timiryazev Institute of Plant Physiology, 35 Botanicheskaya St Moscow 127276, Russia.

To Cite This Article: Marina I Azarkovich. Protein Complex as Indicator of Seed Recalcitrance. Am J Biomed Sci \& Res. 2019 - 6(2). AJBSR. MS.ID.001011. DOI: 10.34297/AJBSR.2019.06.001011.

Received: 㘹 November 04, 2019; Published: 些 November 13, 2019

\section{Introduction}

Late stage of seed ripening and storage compounds accumulation is accompanied with maturation drying, seeds become desiccation tolerant, and may survive for a long time in the dry state. These seeds are named orthodox. However, part of species, especially originated from tropics, produces so-called recalcitrant seeds. Recalcitrant seeds do not dry at the end of maturation, they have high moisture content and active metabolism; recalcitrant seeds remain desiccation sensitive. Seed recalcitrance is often found in moist, warm climatic zones, without seasonal changing [1,2]. In tropical rainforests seed recalcitrance and fast germination of moist seeds gives preference to a species [3]. But recalcitrant seeds are not storable for a long time, and it is a problem for agriculture. Predicting of seed storage behavior is very important for seed preservation, seed banks, for developing an ex-situ conservation strategy. Different tests have been developed for estimation of seed desiccation tolerance or sensitivity [4].

It should be noted, that germination test does not give reliable results, if seeds are in the state of deep dormancy. Dormancy prevents seed germination during unfavorable seasons (autumn and winter in temperate climate). Some authors pay attention to levels of sucrose and raffinose family oligosaccharides (RFOs) and ratio of di- and oligosaccharides during seed maturation [5-7]. Seed sugars are proposed to be an indicator of seed recalcitrance [5].

The mature horse chestnut (Aesculus hippocastanum L.) seeds are recalcitrant, but they are having high water content, survive under snow during winter. Horse chestnut seeds have deep dormancy and need cold wet stratification for dormancy release.

We have analyzed protein complex in horse chestnut seeds $[8,9]$ and did not found typical seed storage proteins. Cells of axes and cotyledons of seeds under investigation contained extremely low quantity of globulins, and high level of non-compartmentalized heat-stable proteins. Heat-stable proteins comprised about $30 \%$ of soluble cytosolic proteins in cells of seed axes and more than $80 \%$ in cotyledons $[8,9]$. These characteristics of horse chestnut seed proteome may be related to the specific features of physiological behavior recalcitrant horse chestnut seeds. The protein composition differs recalcitrant seeds from the majority of orthodox seeds. The histochemical analysis (protein staining in the cells of axes and cotyledons) did not detect considerable depositions of proteins or formed protein bodies in the cells of axes and in the storage parenchyma of cotyledons of dormant horse chestnut seeds before and during stratification. Cell vacuoles were preserved in mature seeds and vacuoles were optically empty [10]. We found similar cell structure and fraction composition of proteins in another species growing in Central Russia and producing recalcitrant seeds - English oak (Quercus robur) [11].

It might be supposed that in recalcitrant horse chestnut seeds the presence of a great amount of hydrophilic proteins capable of holding water is related to the recalcitrancy of seeds. It might be as well that these proteins could improve seed tolerance to long-term action of low temperature in spite of their high hydration and thus maintain embryo vitality under conditions of cold stratification or snow in winter. The presence of a great amount of hydrophilic heat-stable proteins in cytosol and the absence of typical storage proteins and protein bodies may serve a diagnostic indication of seed recalcitrance.

\section{References}

1. Tweddle JC, Dickie JB, Baskin CC, Baskin JM (2003) Ecological aspects of seed desiccation sensitivity. Journal of Ecology 91: 294-304.

2. Wyse SV, Dickie JB (2017) Predicting the global incidence of seed desiccation sensitivity. Journal of Ecology 105: 1082-1093.

3. Kleinwächter M, Radwan A, Hara M, Selmar D (2014) Dehydrin expression in seeds: an issue of maturation drying. Frontiers in Plant Science. 5(402): 1-3. 
4. Pritchard HW, Wood CB, Hodges S, Vautier HJ (2004) 100-seed test for desiccation tolerance and germination: a case study on eight tropical palm species. Seed Science and Technology 32(2): 393-403.

5. Steadman KJ, Pritchard HW, Dey PM (1996) Tissue-specific soluble sugars in seeds as indicators of storage category. Annals of Botany 77(6): 667-674.

6. Bailly C, Audigier C, Ladonne F, Wagner MH, Coste F, et al. (2001) Changes in oligosaccharide content and antioxidant enzyme activities in developing bean seeds as related to acquisition of drying tolerance and seed quality. J Exp Bot 52(357): 701-708.

7. Pukacka S, Ratajczak E, Kalemba E (2009) Non-reducing sugar levels in beech (Fagus sylvatica) seeds as related to withstanding desiccation and storage. J Plant Physiol 166(13): 1381-1390.
8. Gumilevskaya NA, Azarkovich MI, Komarova ME, Obroucheva NV (2001) Proteins of Axial Organs of Dormant and Germinating Horse Chestnut Seeds: 1. General Characterization. Russian Journal of Plant Physiology 48(1): 1-11.

9. Azarkovich MI, Gumilevskaya NA (2006) Proteins of Cotyledons of Mature Horse Chestnut Seeds. Russian Journal of Plant Physiology 53(5): 629-637.

10. Azarkovich MI, Bolyakina Yu P (2016) Recalcitrant Seeds of Horse Chestnut Lack Protein Bodies. Russian Journal of Plant Physiology 63(4): 499-504.

11. Azarkovich MI, Nazarenko LV (2014) Are There Aleurone Grains in Recalcitrant Seeds of Quercus robur L.? MCTTU Vestnik Series "Natural Sciences" 4(16): 39-45 